\title{
Control of infective larvae of gastrointestinal nematodes in heifers using different isolates of nematophagous fungi
}

\author{
Controle de larvas infectantes de nematóides gastrintestinais de novilhas \\ por diferentes isolados dos fungos nematófagos \\ Manoel Eduardo da Silva ${ }^{1,2}$; Jackson Victor de Araújo ${ }^{1 *}$; Fabio Ribeiro Braga ${ }^{1,3}$; \\ Filippe Elias de Freitas Soares ${ }^{4}$; Daniel Sobreira Rodrigues ${ }^{5}$
}

\author{
${ }^{1}$ Departamento de Veterinária, Universidade Federal de Viçosa - UFV, Viçosa, MG, Brasil \\ ${ }^{2}$ Empresa de Pesquisa Agropecuária de Minas Gerais - EPAMIG, Belo Horizonte, MG, Brasil \\ ${ }^{3}$ Universidade Vila Velha - UVV, Vilha Velha, ES, Brasil \\ ${ }^{4}$ Departamento de Bioquímica e Biologia Molecular, Universidade Federal de Minas Gerais - UFMG, Belo Horizonte, MG, Brasil \\ ${ }^{5}$ Escola de Veterinária, Universidade Federal de Minas Gerais - UFMG, Belo Horizonte, MG, Brasil
}

Received June 19, 2012

Accepted September 12, 2012

\begin{abstract}
The effect of different nematophagous fungi [Duddingtonia flagrans (AC001 and CG722) and Monacrosporium thaumasium (NF34)] with regard to controlling infective larvae $\left(\mathrm{L}_{3}\right)$ of nematodes after gastrointestinal transit in female cattle $(3 / 4$ Holstein $\times$ Zebu) was evaluated. A total of 24 pubescent female cattle were used, weighing approximately $320 \mathrm{~kg}$ each one. There were three treatment groups, each contained six animals that received $150 \mathrm{~g}$ of pellets $(0.2 \mathrm{~g}$ of mycelium), orally in a single dose, in a sodium alginate matrix containing mycelial mass of the fungus D. flagrans (AC001 or CG722) or M. thaumasium (NF34); and one control group (without fungi). Fecal samples were collected from the animals at intervals of $12,15,18,21,24,48$, and 72 hours. At the end of 17 days, the $\mathrm{L}_{3}$ not subjected to predation were recovered by means of the Baermann method. The fungal isolates tested were capable of destroying the $\mathrm{L}_{3}$ after gastrointestinal transit. It was observed that within 72 hours, the isolates AC001, CG722, and NF34 showed a higher predatory activity $(81.2 \%, 97.3 \%$, and $98.3 \%$, respectively). The results justify the need for studies in the field, and over longer intervals, in order to observe the efficiency of the fungus $D$. flagrans, or even M. thaumasium, for environmental control over nematodes in naturally infected cattle.
\end{abstract}

Keywords: Nematophagous fungi, Duddingtonia flagrans, Monacrosporium thaumasium, nematodes, cattle.

\section{Resumo}

No presente estudo, foi avaliado o efeito de diferentes fungos nematófagos [Duddingtonia flagrans (AC001 e CG722) e Monacrosporium thaumasium (NF34)] no controle de larvas infectantes $\left(\mathrm{L}_{3}\right)$ de nematóides após o trânsito gastrointestinal em fêmeas bovinas (3/4 Holandês x Zebu). Um total de 24 fêmeas bovinas pubescentes foram utilizadas, pesando aproximadamente $320 \mathrm{~kg}$ cada. Foram utilizados três grupos de tratamento; cada um contendo seis animais que receberam por via oral de $150 \mathrm{~g}$ de péletes $(0,2 \mathrm{~g}$ de micélio), em dose única, em uma matriz de alginato de sódio contendo massa micelial dos fungos D. flagrans (AC001 ou CG722), M. thaumasium (NF34), além de um grupo controle (sem fungo). Amostras de fezes foram colhidas dos animais em intervalos de 12, 15, 18, 21, 24, 48 e 72 horas. No final de 17 dias, as $\mathrm{L}_{3}$ não predadas foram recuperadas pelo método de Baermann. Os isolados de fungos testados foram capazes de destruir as $\mathrm{L}_{3}$ após trânsito gastrointestinal. Observou-se após 72 horas, os isolados AC001, CG722 e NF34 mostraram uma maior atividade predatória $(81,2 \%, 97,3 \%$ e $98,3 \%$, respectivamente). Estes resultados justificam a necessidade de estudos a campo e em intervalos mais longos, a fim de observar a eficácia dos fungos $D$. flagrans ou mesmo $M$. thaumasium no controle ambiental dos nematóides de bovinos naturalmente infectados.

Palavras-chave: Fungos nematófagos, Duddingtonia flagrans, Monacrosporium thaumasium, nematóides, bovinos.

\footnotetext{
*Corresponding author: Jackson Victor de Araújo

Departamento de Veterinária, Universidade Federal de Viçosa - UFV,

Viçosa, MG, Brasil

e-mail: jvictor@ufv.br
} 


\section{Introduction}

Cattle, goats, and sheep represent one of the main sources of protein for the human population. However, one of the obstacles to their production worldwide is gastrointestinal helminthosis. This is the disease most often responsible for damage to livestock, with estimated costs around of 68 million dollars a year, since almost all animals produced in the field harbor one or more species of helminth (ANUALPEC, 2003; TORINA et al., 2004; AMARANTE, 2009).

The country with the largest commercial cattle herd in the world is Brazil. However, because cattle production most often takes place wholly or partly on pasture, there is constant infection due to parasites present in the grazing land (ANUALPEC, 2003). Because of this, gastrointestinal nematodes are a serious problem in ruminant production; once the animals have been exposed to high parasite loads they may succumb, especially younger individuals, which are more susceptible (AMARANTE, 2009).

In this context, nematodes, especially the genus Haemonchus, are responsible for large economic losses in livestock (URQUHART et al., 1996; AMARANTE, 2011). The conventional method for controlling such gastrointestinal parasites is to use synthetic anthelmintic drugs. However, over recent decades there has been increasing interest in developing new methods for controlling nematode parasites of livestock. The main reason for this has been the increasing development of anthelmintic resistance in several species of parasitic nematodes in ruminants, including anthelmintic resistance among nematode parasites in cattle (FIEL et al., 2001; ARAÚJO et al., 2004a; CONDI et al., 2009; SUTHERLAND; LEATHWICK, 2011).

Thus, use of nematophagous fungi, in particular of the species Duddingtonia flagrans and Monacrosporium thaumasium, as an alternative control has been constantly tested, with interesting results both in the field and under laboratory conditions (BRAGA et al., 2009, 2011a; SILVA et al., 2009; PAZ-SILVA et al., 2011; TAVELA et al., 2011). In addition, passage of different fungal structures, as well as of different isolates of the same species of fungus, through the gastrointestinal tract of different animal species has been the target of several studies (LARSEN, 1999; GRONVOLD et al., 1993, 1996). In this context, the challenge of these studies has been to investigate whether there are differences in viability and predatory activity of these fungi after suffering 'stress' during passage through the gastrointestinal tract of animals. The best fungal isolates, exhibiting the characteristics of potential biological controls while being marketable through production of chlamydospores (resistant structures) need to be identified.

The objective of the present study was to evaluate the effect of different nematophagous fungi in relation to controlling the infective larvae $\left(\mathrm{L}_{3}\right)$ of gastrointestinal nematodes, after gastrointestinal transit in female cattle $(3 / 4$ Holstein $\times$ Zebu).

\section{Materials and Methods}

\section{Fungi}

Two isolates of the nematophagous fungus D. flagrans (AC001 and CG722) and one isolate of the fungus M. thaumasium
(NF34) were used. These isolates were obtained from Brazilian agricultural soil, in the municipality of Vicosa, in the Zona da Mata region of the state of Minas Gerais. They were collected using the soil-sprinkling method of Duddington (1955).

\section{Production of mycelial mass}

To produce fungal mycelia of $D$. flagrans (AC001 and CG722) and $M$. thaumasium (NF34), culture discs of approximately $4 \mathrm{~mm}$ in diameter, in $2 \%$ water agar $(2 \% \mathrm{WA})$ were transferred to $250 \mathrm{~mL}$ Erlenmeyer flasks containing $150 \mathrm{~mL}$ of the liquid medium GPY (glucose, sodium peptone and yeast extract). The flasks were continually stirred at $120 \mathrm{rpm}$, in the dark and at the temperature of $26^{\circ} \mathrm{C}$, for 10 days. After this period, the mycelia were removed, filtered, and weighed on an analytical balance. All the procedures followed the methodology of Braga et al. (2009).

\section{Animals}

A total of 24 pubescent female cattle $(3 / 4$ Holstein $\times$ Zebu) of approximate age 20 months were used. Their live weight was approximately $320 \mathrm{~kg}$ each one. Throughout the experiment the animals were kept in stalls in a cowshed and were fed with sugarcane plus urea and $16 \%$ protein concentrate. These animals were on the Santa Rita Experimental Farm, which is owned by the Agricultural Research Corporation of Minas Gerais (Empresa de Pesquisa Agropecuaria de Minas Gerais, EPAMIG).

\section{Experimental assay}

For the in vivo assay, the animals were kept in stalls and were dewormed using 1\% ivermectin (Ivergen ${ }^{\circledR}$, Biogenesis, Brasil $200 \mu \mathrm{g} / \mathrm{kg}$ body weight) 45 days before receiving the experimental diet. They were then separated into four groups of six animals each: one group was fed with alginate pellets containing the D. flagrans isolate AC001; one group received pellets containing D. flagrans CG722; and a third group received pellets containing $M$. thaumasium NF34. The fourth group remained served as control group and was fed pellets without fungi.

In the groups treated with AC001, CG722, and NF34, each animal received $150 \mathrm{~g}$ of pellets in a single dose containing mycelial mass of the respective fungus ( $0.2 \mathrm{~g}$ of mycelium). For this, each of the fungi was mixed in $500 \mathrm{~g}$ of feed for cattle with $16 \%$ protein. The animals in the control group received a single administration of $150 \mathrm{~g}$ of pellets without fungi plus $500 \mathrm{~g}$ of feed.

Later, after administration of the fungi, fecal samples were collected from the animals at intervals of 12, 15, 18, 21, 24, 48, and 72 hours afterwards. About $30 \mathrm{~g}$ of feces from each animal in each of the treated and control groups were homogenized to form a 'pool' for each experimental group. Next, from the fecal material collected (the 'pool') at the different times after fungus administration, coprocultures were performed in accordance with the technique described by Roberts and O'Sullivan (1952). At each set time (12, 15, 18, 21, 24, 48, and 72 hours), six repetitions were performed for each coproculture, for each of the treated and control groups, totaling 24 samples per time and a total of 168 coprocultures. These coprocultures were incubated 
in a BOD chamber at $26^{\circ} \mathrm{C}$ and were protected from light for 17 days. After this period, the $\mathrm{L}_{3}$ that had not been subjected to predation were recovered in hemolysis tubes with the aid of the Baermann apparatus, and were quantified and identified in accordance with the criteria proposed by Keith (1953). For this, we used optical microscope objective lenses of $10 \times$ and $40 \times$. The data obtained were subjected to analysis of variance ( $F$ test) and subsequent regression analysis. Means were compared using the Tukey test at the 5\% level of probability (AYRES et al., 2003).

\section{Results}

In the present study, it was observed that the fungi $D$. flagrans (AC001 or CG722) and M. thaumasium (NF34) destroyed the $\mathrm{L}_{3}$ of gastrointestinal nematodes after transit through the gastrointestinal tract of cattle. In the feces of the treated groups, conidia and chlamydospores of the fungal species tested (D. flagrans and $M$. thaumasium) were identified, and $\mathrm{L}_{3}$ that had been subjected to predation could be viewed (Figures 1a-d). For each time studied, the fungi showed a percentage reduction in the number of $\mathrm{L}_{3}$ recovered from the coprocultures using the Baermann method after 17 days that ranged from $87 \%$ to $81.2 \%$ for the AC001 isolate, from $88.4 \%$ to $97.3 \%$ for NF34 and from $98.2 \%$ to 98.3\% for CG722 (Figure 2). Comparisons with the control group are shown in Figure 3.

On the other hand, over the sampling time, there was no difference $(p>0.05)$ in the action of the fungal isolates tested, and therefore in the recovery of $\mathrm{L}_{3}$ at the end of 17 days. However, the CG722 isolate showed better performance than shown by AC001 and NF34. In relation to identification of the $\mathrm{L}_{3}$ obtained from coprocultures, it was observed that the genus Haemonchus was the most prevalent, accounting for 69\%, then Oesophagostomum with $26 \%$ and Cooperia with $5 \%$.

\section{Discussion}

The fungi tested (AC001, NF34 and CG722) were able to remain viable following gastrointestinal transit through naturally infected cattle, and thus their predatory activity was demonstrated at the end of the experiment (Figures 1a-d and
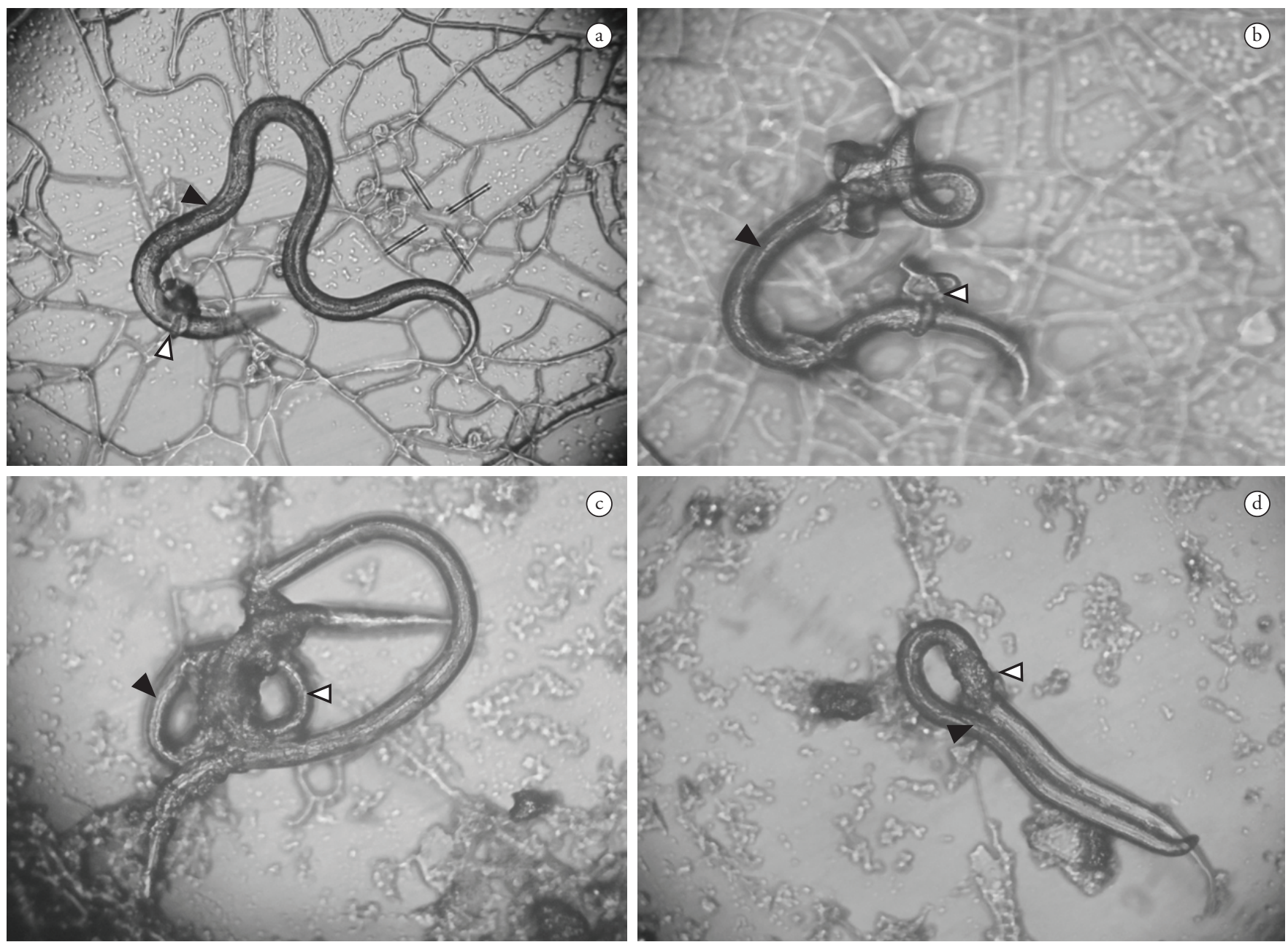

Figure 1. a-d) Infective larvae captured by nematophagous fungi [Duddingtonia flagrans (AC001 and CG722) and Monacrosporium thaumasium (NF34)] (white arrow) in Petri dishes containing 2\% water-agar, and trap formation by the fungal isolates (black arrow). Magnification: (a) $10 \times$ and (d) $40 \times$ objective lens. 
Figure 2). Therefore, they may be used in other studies in the field. It is worth remembering that in the present study, the genus Haemonchus was the most prevalent, confirming the studies confirming previous studies. Moreover, these results are compatible with other reports regarding the passage and predatory activity of nematophagous fungi in relation to in vitro and in vivo control of gastrointestinal nematodes in cattle (ARAÚJO et al., 2004b).

Use of nematophagous fungi for biologically controlling the gastrointestinal parasites of domestic animals reduces soil contamination, since these fungi act directly on $\mathrm{L}_{3}$ present in the environment (LARSEN, 1999; ARAÚJO et al., 2004a). Studies conducted in several regions in Brazil have shown higher prevalence of the genera Cooperia, Haemonchus, Oesophagostomum, Trichostrongylus, Trichuris, and Bunostomum in cattle (FURLONG et al., 1985). This premise is concordant with Lima (1989), who stated that the $\mathrm{L}_{3}$ of parasitic nematode species are available in pastures almost all year round, thus serving as a continuous source of infection for animals.

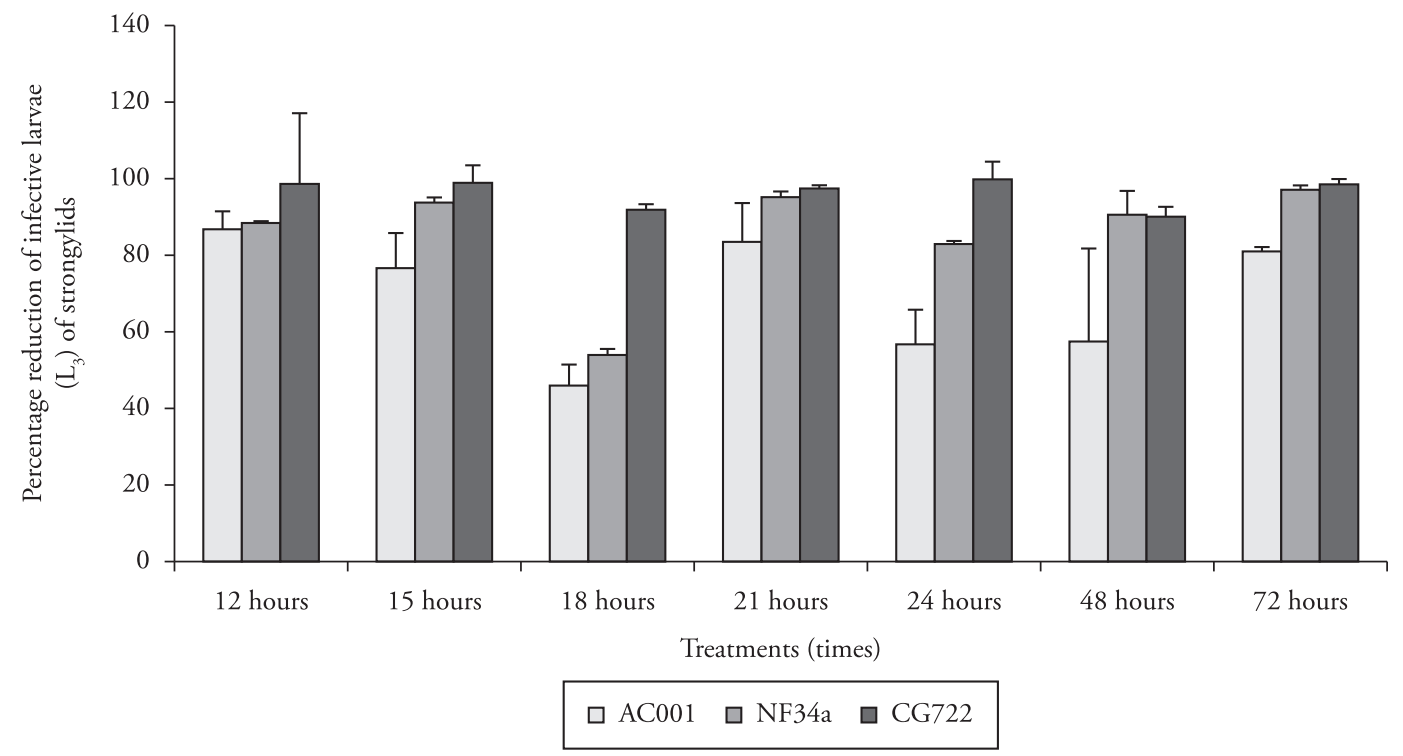

Figure 2. Mean percentage reduction of nematode infective larvae $\left(\mathrm{L}_{3}\right)$ recovered from coprocultures by means of the Baermann method after 17 days of incubation with the fungal isolates Duddingtonia flagrans (AC001 or CG722) and Monacrosporium thaumasium (NF34) obtained at the times of $12,15,18,21,24,48$, and 72 hours.

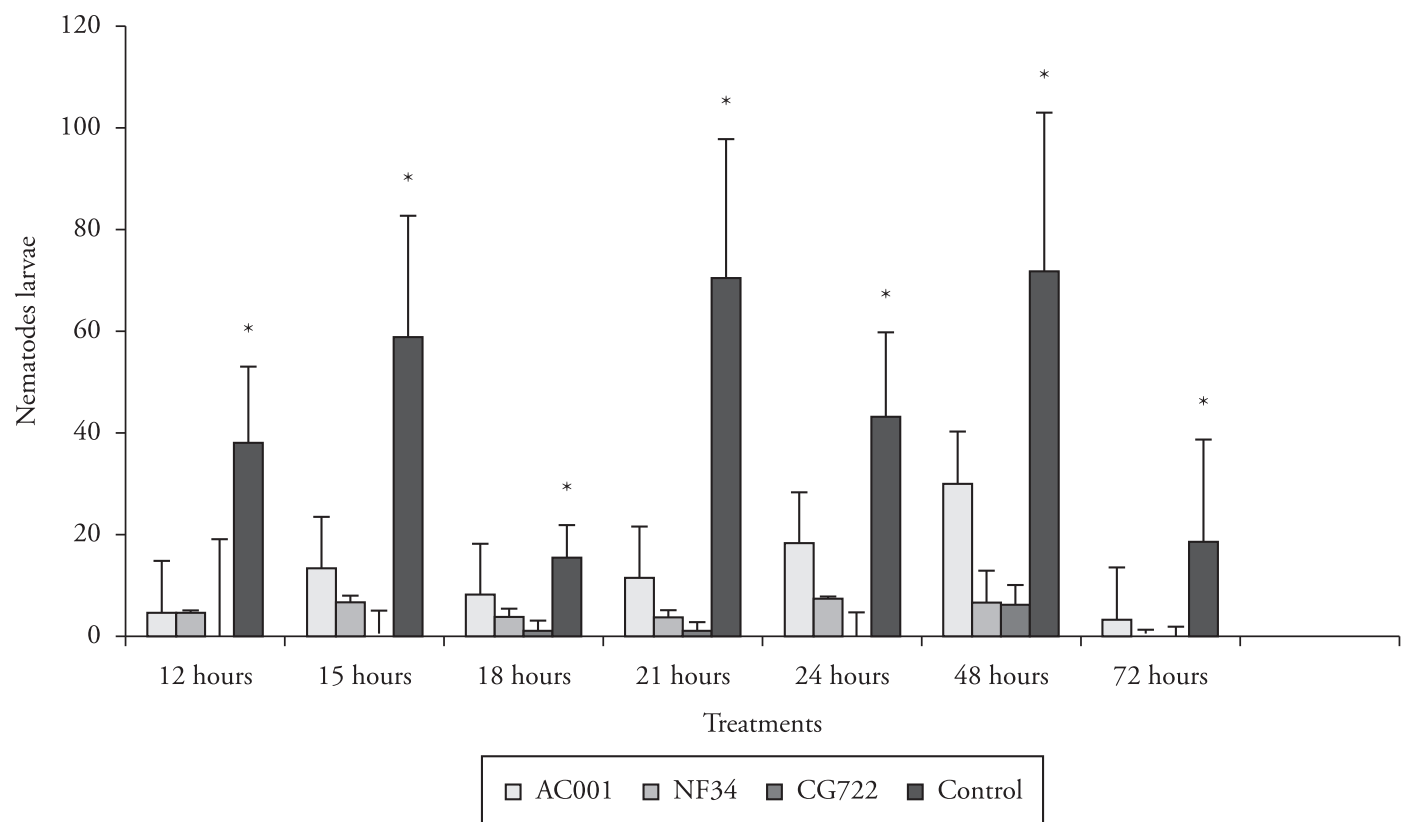

Figure 3. Mean numbers of infective larvae $\left(\mathrm{L}_{3}\right)$ recovered by means of the Baermann method from coprocultures after 17 days of treatment with the fungal isolates Duddingtonia flagrans (AC001 or CG722) or Monacrosporium thaumasium (NF34), and in the control group (without fungi). ${ }^{*}$ Statistical difference $(p<0.01)$ among the isolates tested in relation to the control group at the sampling times. 
Regarding the results relating to the degree of reduction in the quantities of $\mathrm{L}_{3}$ recovered from coprocultures, it was found that the three isolates tested (AC001, NF34 and CG722) showed similarity in their predatory activity $(p>0.05)$, which was thus reflected in the high numbers of larvae destroyed. It should be noted that although this experimental assay was conducted in coprocultures, the same data could be extrapolated for future assays in the field, especially if a longer time interval were to be studied. Moreover, any of the isolates tested could be used, except for some peculiarities of each species (BRAGA et al., 2011b).

In the literature, it has been reported that the most practical way to use the fungi D. flagrans (AC001 or CG722) and $M$. thaumasium, or any other nematophagous fungus, is by means of oral administration of fungal material in the form of mycelium, conidia and/or chlamydospores. Inoculation of these organisms into a sodium alginate matrix, to form pellets, is a more recent method that has presented good results (LARSEN, 1992; ARAÚJO et al., 2004a; DIAS et al., 2007; TAVELA et al., 2011). On the other hand, there has been much discussion on the use of different isolates of the same species of fungus under the same conditions, in this case partly natural, which could present distinct results. In this regard, inter and intraspecific differences in the predatory activity of nematophagous fungi are common and have already been observed in experiments with other fungal isolates (MENDOZA-DE-GUIVES et al., 1999).

The species D. flagrans (isolates AC001 and CG722) has been tested both under laboratory conditions and in the field. In the past, Gronvold et al. (1993) observed a reduction in the levels of Ostertagia ostertagi $\mathrm{L}_{3}$ in the fecal mass of calves, when these were fed with barley grain containing the fungus $D$. flagrans. In another study, Dias et al. (2007) demonstrated that treatment of young cattle with pellets containing the fungus $D$. flagrans (CG722) was effective in reducing the number of eggs per gram of feces and consequently in reducing the number of $\mathrm{L}_{3}$ of gastrointestinal nematodes obtained from coprocultures. Those results are in agreement with the present study, in which the fungus was also observed to be an efficient predator. However, it is worth remembering that even though there was no difference $(p>0.05)$ in the reduction of $\mathrm{L}_{3}$ recovered from coprocultures according to the isolate used, CG722 proved to be more efficient, with a percentage reduction of $98.3 \%$ after 72 hours, whereas the reduction with AC001 was 81.2\%. However, there are few reports of comparisons between the isolates AC001 and CG722 of $D$. flagrans, used for controlling nematode parasites in naturally infected Holstein cattle.

Araújo et al. (2004b) evaluated the resistance of the nematophagous fungus $M$. sinense (isolate SF470) to passage through the gastrointestinal tract of cattle and its subsequent predatory ability on infective trichostrongylid larvae. In that study, a $61.3 \%$ difference in $\mathrm{L}_{3}$ recovery from coprocultures at the end of the experiment was reported. Furthermore, it was observed that the number of $\mathrm{L}_{3}$ of gastrointestinal nematodes recovered from the animals of the control group was higher $(p<0.05)$ than that of the treated group. In another study, Araújo and Ribeiro (2003) demonstrated that the isolates $M$. appendiculatum (CGI) and $M$. sinense (SF53) had the capacity to pass through the gastrointestinal tract of cattle and observed that conidia were present after 14 days of incubation. Those results are in agreement with the present study, since the tested isolate of $M$. thaumasium (NF34) was able to cause a reduction (97.3\%) in the number of $\mathrm{L}_{3}$ recovered at the end of 17 days. In addition, the fungal structures were also observed to be in agreement with this genus.

Lastly, although use of nematophagous fungi for biologically controlling nematode parasites in ruminants has been widely studied, the present authors take the view that such control will only become possible after commercial organizations start to be involved in developing fungal formulations. On the other hand, the present results justify the need for studies in the field, over longer intervals, in order to observe the efficiency of the fungi D. flagrans (AC001 or CG722) or M. thaumasium (NF34) for environmental control over nematodes in naturally infected cattle. Through this, in the future, it will be possible to assess the best approach towards integrated control over bovine helminths.

\section{Acknowledgements}

The authors thank FAPEMIG, CAPES and CNPq for financial support.

\section{References}

Amarante AFT. Nematoides gastrintestinais em ovinos. In: Cavalcante AC, Vieira LS, Chagas ACS, Molento MB. Doenças parasitárias de caprinos e ovinos epidemiologia e controle. Brasília: Embrapa Informação Tecnológica; 2009. p. 17-62

Amarante AFT. Why is it important to correctly identify Haemonchus species? Rev Bras Parasitol Vet 2011; 20(4): 263-268. PMid:22166378. http://dx.doi.org/10.1590/S1984-29612011000400002

Anuário da Pecuária Brasileira - Anualpec. Anuário estatístico da produção animal. São Paulo: FNP Consultoria \& Comércio; 2003. 380 p.

Araújo JV, Mota MA, Campos AK. Controle de helmintos de animais por fungos nematófagos. Rev Bras Parasitol Vet 2004a; 13(S1): 165-170.

Araújo JV, Assis RCL, Alves PH, Campos AK, Granda JR. Controle biológico de tricostrongilídeos (Nematoda: Trichostrongyloidea) gastrintestinais de bovinos pelo fungo Monacrosporium sinense. Arq Bras Med Vet Zootec 2004b; 56(4): 467-471. http://dx.doi.org/10.1590/ S0102-09352004000400007

Araújo JV, Ribeiro RR. Atividade predatória sobre larvas de tricostrongilídeos (Nematoda: Trichostrongyloidea) de isolados fúngicos do gênero Monacrosporium após a passagem pelo trato gastrintestinal de bovinos. Rev Bras Parasitol 2003; 12(2): 76-81.

Ayres M, Ayres JRM, Ayres DL, Santos AS. Aplicaçôes estatísticas nas áreas de ciências biológicas. Belém: Sociedade Civil Mamirauá; Brasília: CNPq; 2003. p. 290.

Braga FR, Araújo JV, Silva AR, Araujo JM, Carvalho RO, Tavela $\mathrm{AO}$, et al. Biological control of horse cyathostomin (Nematoda: Cyathostominae) using the nematophagous fungus Duddingtonia flagrans in tropical southeastern Brazil. Vet Parasitol 2009; 163(4): 335-340. PMid:19497672. http://dx.doi.org/10.1016/j.vetpar.2009.05.003

Braga FR, Araújo JV, Araujo JM, Tavela AO, Ferreira SR, Soares FEF, et al. Influence of the preservation period in silica-gel on the predatory activity of the isolates of Duddingtonia flagrans on 
infective larvae of cyathostomins (Nematoda: Cyathostominae). Exp Parasitol 2011a; 128(4): 460-463. PMid:21627962. http://dx.doi. org/10.1016/j.exppara.2011.05.013

Braga FR, Araújo JV, Soares FEF, Araujo JM, Ferreira SR, Frassy LN, et al. Production and partial characterization of Duddingtonia flagrans (AC001) crude extract and its in vitro larvicidal action against trichostrongylid infective larvae. Biocontrol Sci Technol 2011b, 21(11): 1313-1320. http:// dx.doi.org/10.1080/09583157.2011.619258

Condi GK, Soutello RVG, Amarante AFT. Moxidectin-resistant nematodes in cattle in Brazil. Vet Parasitol 2009; 161(3-4): 213-217. PMid:19251366. http://dx.doi.org/10.1016/j.vetpar.2009.01.031

Dias AS, Araújo JV, Campos AK, Braga FR, Fonseca TA. Application of a formulation of the nematophagous fungus Duddingtonia flagrans in the control of cattle gastrointestinal nematodiosis. World J Microbiol Biotechnol 2007; 23(9): 1245-1252. http://dx.doi.org/10.1007/s11274007-9356-0

Fiel CA, Saumell CA, Steffan PE, Rodriguez EM. Resistance of Cooperia to ivermectin treatments in grazing cattle of the Humid Pampa, Argentina. Vet Parasitol 2001; 97(3): 211-217. http://dx.doi. org/10.1016/S0304-4017(01)00407-1

Furlong J, Abreu HGL, Verneque RS. Parasitoses dos bovinos da zona da mata de Minas Gerais. I. Comportamento estacional de nematódeos gastrintestinais. Pesq Agropec Bras 1985; 20(2): 143-153.

Gronvold J, Henriksen SA, Larsen M, Nansen P, Wolstrp J. Biological control Aspects of biological control, with special reference to arthropods, protozoans and helminths of domesticated animals. Vet Parasitol 1996; 64(1-2): 47-64. http://dx.doi.org/10.1016/03044017(96)00967-3

Gronvold J, Wolstrup J, Nansem P, Henriksen SA, Larsen M, Bresciani J. Biological control of nematode parasites in cattle with nematode trapping fungi: a survey of Danish studies. Vet Parasitol 1993; 48(1-4): 311- 325. http://dx.doi.org/10.1016/0304-4017(93)90165-J

Keith RK. The differentiation on the infective larvae of some common nematode parasites of cattle. Australian J Zool 1953; 1(2): 223-235. http://dx.doi.org/10.1071/ZO9530223

Larsen M. Biological control of helminths. Int J Parasitol 1999; 29(1): 139146. http://dx.doi.org/10.1016/S0020-7519(98)00185-4

Larsen M, Wolstrup J, Henriksen SA, Gronvold J, Nansen P. In vivo passage through calves of nematophagous fungi selected for biocontrol of parasitic nematodes. J Helminthol 1992; 66(2): 137-141. PMid:1640088. http://dx.doi.org/10.1017/S0022149X00012724

Lima WS. Dinâmica de populaçôes de nematoides parasitos gastrointestinais em bovinos de corte: alguns aspectos da relação parasito-hospedeiro e do comportamento de estádios de vida livre na regiáo do Vale do Rio Doce, MG, Brasil [Dissertação]. Belo Horizonte: Universidade Federal de Minas Gerais; 1989.

Mendoza-De-Guives P, Davies KG, Clarck SJ, Behnke JM. Predatory behaviour of trapping fungi against $s r f$ mutants of Caenorhabditis elegans and different plant and animal parasitic nematodes. Parasitol 1999; 119(1): 95-104. http://dx.doi.org/10.1017/ S0031182099004424

Paz-Silva A, Francisco I, Valero-Coss R, Cortińas F, Sánchez J, Francisco R, et al. Ability of the fungus Duddingtonia flagrans to adapt to the cyathostomin egg-output by spreading chlamydospores. Vet Parasitol 2011; 179(1-3): 277-282. PMid:21402449. http://dx.doi. org/10.1016/j.vetpar.2011.02.014

Roberts FHS, O'Sullivan PJ, Riek RF. The epidemiology of parasitic gastro-enteritis of cattle. Aust J Agric Res 1952; 3(2): 87-226. http:// dx.doi.org/10.1071/AR9520187

Silva AR, Araújo JV, Braga FR, Frassy LN, Tavela AO, Carvalho $\mathrm{RO}$, et al. Biological control of sheep gastrointestinal nematodiasis in a tropical region of the southeast of Brazil with the nematode predatory fungi Duddingtonia flagrans and Monacrosporium thaumasium. Parasitol Res 2009; 105(6): 1707-1713. PMid:19756749. http://dx.doi. org/10.1007/s00436-009-1613-8

Sutherland IA, Leathwick DM. Anthelmintic resistance in nematode parasites of cattle: a global issue? Trends Parasitol 2011; 27(4): 176-181. PMid:21168366. http://dx.doi.org/10.1016/j.pt.2010.11.008

Tavela AO, Araújo JV, Braga FR, Silva AR, Carvalho RO, Araujo JM, et al. Biological control of cyathostomin (Nematoda: Cythostominae) with nematophagous fungus Monacrosporium thaumasium in tropical southeastern Brazil. Vet Parasitol 2011; 175(1-2): 92-96. PMid:21035270. http://dx.doi.org/10.1016/j.vetpar.2010.09.035

Torina A, Ferrantelli V, Sparagano OAE, Reale S, Vitale F, Caracappa S. Climatic conditions and gastrointestinal nematode egg production: Observations in breeding sheep and goats. Ann $N Y$ Acad Sci 2004; 1026(1): 203-209. PMid:15604494. http://dx.doi. org/10.1196/annals.1307.031

Urquhart GM, Aramour J, Duncan JL. Veterinary Parasitology. London: Blackwell Science; 1996. 